В заключении, необходимо выделить основные способы повышения процесса обучения:

- за счет использования современных технологий обучения;

- $\quad$ за счет активизации роли каждого обучающегося в учебном процессе.

Можно утверждать, что при изменении способа подачи учебных материалов, использовании современных технологий, различных форм и приёмов на занятиях по дисциплине «Физика, математика» - позволяет развить личностную заинтересованность и самостоятельность каждого студента к учебной деятельности, желанию понимать для чего эти знания необходимы будущему врачу, а также активизировать познавательную деятельность и память. Использование технологии модульного обучения приводит к увеличению качества знаний по дисциплине «Физика, математика».

$$
* * *
$$

1. Иванова О.Ю., Антонова Ю.Н. Технология модульного обучения иностранному языку как средство организации самостоятельной работы бакалавров// Проблемы лингвистики, методики обучения иностранным языкам и литературоведения в свете межкультурной коммуникации: сборник материалов II Международной научно-практической Интернет-конференции (27-28 февраля 2017 г.) / под ред. О.Ю. Ивановой. Орел: ФГБОУ ВО «ОГУ имени И.С. Тургенева», 2017. С. 185-189.

2. Плащевая Е.В., Нигей Н.В. Смирнов В.А., Лысак В.А. Лабораторный практикум по дисциплине «Физика, математика» раздел «Физика». Благовещенск, Амурская ГМА, 2020 г. С. 219.

3. Плащевая, Е. В. Методические особенности проведения лабораторных работ по физики в медицинском вузе / Е. В. Плащевая, Н. В. Нигей // Проблемы управления качеством образования: Сборник статей XIII Всероссийской научно-практической конференции, Пенза, 28-29 декабря 2020 года. - Пенза: Пензенский государственный аграрный университет, 2020. - С. 130-136.

4. Плащевая, Е. В. Особенности применения интерактивных методов обучения в курсе физики медицинского вуза / Е. В. Плащевая, Н. В. Нигей // Тенденции развития науки и образования. - 2021. - № 75-4. - С. 121123. - DOI 10.18411/lj-07-2021-147.

\title{
Плащевая Е.В. \\ Формирование личности будущего врача в цифровом образовательном пространстве в процессе изучения медицинской информатики
}

ФГБОУ ВО «Амурская государственная медищинская академия»

(Россия, Благовещенск)

doi: 10.18411/trnio-01-2022-150

\section{Аннотация}

В данной статье рассматривается и обосновывается необходимость использования цифровых технологий для развития личности будущего врача. Цифровая грамотность позволяют молодому врачу войти в информационную среду XXI века технологически компетентным специалистом и личностно развитым человеком. И самое главное современные студенты нуждаются в этой поддержке при включении их в цифровое образовательное пространство.

Ключевые слова: будущие врачи, цифровые технологии, образовательное пространство, студент, личность.

\section{Abstract}

This article discusses and justifies the need to use digital technologies for the development of the personality of a future doctor. Digital literacy allows a young doctor to enter the information environment of the XXI century as a technologically competent specialist and a personally developed person. And most importantly, modern students need this support when they are included in the digital educational space.

Keywords: future doctors, digital technologies, educational space, student, personality. 
В последнее время весьма важным оказывается понимание того, что развитие нашего общества существенно зависит от уровня образования, что переход в режим последовательного развития общества предполагает внедрение новых цифровых технологий c расчётом на несколько поколений вперед. В XXI веке значимость цифрового образовательного пространства состоит в том, что цифровые информационные технологии применяются во всех без исключения сферах жизни общества, а умения работать с данными технологиями - это залог к повышению качества жизни человека.

Будущие врачи являются представителями нового цифрового поколения и развитие их личности в таких условиях является самой актуальной проблемой. Поэтому, очень важно, учебный процесс строить на понимании и учете разных целей использования ими цифровых технологий (самообразование, самореализация, развлечения, учеба, образование). Важно отметить, что цифровые технологии призваны стать не дополнительным «довеском» в обучении, а неотъемлемой частью целостного образовательного процесса, значительно повышающей его эффективность [1, с. 124].

Цифровые технологии предоставляют практически неограниченные возможности для развития самостоятельной и творческой личности студентов, особенно на занятиях по медицинской информатике. Цифровые технологии являются именно тем средством, с помощью которого педагоги могут качественным образом изменить методы и организационные формы своей работы, полнее развить индивидуальные особенности будущих врачей, осуществлять постоянное обновление организации и формы учебного процесса.

Медицинское образование обеспечивающее развитие личности будущих врачей, в последнее время, не успевает быстро приспосабливаться к росту объемов информации и изменению ее структуры. Причина лежит на поверхности: скорость передачи систематизированной и упорядоченной информации значительно ниже скорости изменений в сфере медицинского знания. В последнее время перед медицинскими ВУЗами стоит задача подготовки врача знающего, мыслящего, владеющего современными информационными технологиями, умеющего самостоятельно добывать и применять знания на практике.

При обучении будущих врачей, особенно на занятиях по медицинской информатике, преподаватели все чаще стали использовать данные технологии:

- практические тренажеры;

- компьютерные тренажеры;

- электронные лаборатории;

- многофункциональные онлайн-курсы;

- электронные библиотеки и т.д.

Причин тому несколько:

- многие эксперименты или демонстрации провести в условиях учебного процесса невозможно (например, из-за дороговизны специальной или лабораторной установки);

- цифровые технологии позволяют глубже понять суть рассматриваемых явлений, т.к. анализ его результатов (которые часто возможно представить в наглядном виде) может помочь исследователю получить новую информацию об изучаемом объекте или процессе и обнаружить эффекты, недоступные для наблюдения в реальном эксперименте и т.д.;

- знакомство с этими технологиями подготовит будущих врачей их к ожидаемым радикальным изменениям в цифровой медицине и здравоохранении.

Помимо этого, внедряющиеся в образовательный процесс цифровые технологии способствуют:

развитию умственного потенциала будущих врачей; 
- формированию умений самостоятельно приобретать и закреплять новые знания;

- осуществлять информационно-учебную, экспериментальноисследовательскую деятельность и разнообразные виды самостоятельной деятельности по обработке новой информации.

Приведём пример задания. Работа в системе МИС «МЕДИАЛОГ».

Ситуация: «В медицинские учреждения были внедрены разные, но функционально схожие, комплексные медицинские информационные системы с функцией ведения электронной медицинской карты. В одном лечебном учреждении среднестатистическое время на заполнение медицинской документации врачом-терапевтом сократилось вдвое, а в другом увеличилось на вдвое» [3, с. 124-127].

Вопрос-задание.

1. Чем можно объяснить такую разницу в эффектах внедрения МИС?

2. Какие необходимо принять организационные меры во втором лечебном учреждении, чтобы сократить время врача на заполнение медицинской документации?

3. Проведите сравнение медицинских информационных систем, сделайте вывод по эффективности применения этих МИС в лечебных учреждениях.

Применение таких заданий в процессе организации самостоятельной работы позволяют в значительной мере не только развивать умственный потенциал и личные качества будущих врачей, но и активизировать учебный процесс. Известно, что информационное окружение будущего врача - самая насыщенная часть образовательного процесса. Прогрессирующее развитие современных цифровых образовательных технологий сегодня как никогда представляет возможность получения необходимых для пользователей данных, сведений, гипотез, теорий. Однако умение получать информацию и преобразовывать её приобретается в процессе обучения и лишь тогда станет фактором личностного развития врача.

$$
* * *
$$

1. Снежицкий В.А., Курбат М.Н., Гущина Л.Н. Современные направления развития информационноинновационной медицинской образовательной среды. Материалы научно-методической конференции, Гродно, ГрГМУ. - 2011 г. - С. 114-115.

2. Плащевая, Е. В. Особенности применения интерактивных методов обучения в курсе физики медицинского вуза / Е. В. Плащевая, Н. В. Нигей // Тенденции развития науки и образования. - 2021. - № 75-4. - С. 121123.

3. Плащевая, Е. В. Основы формирования самостоятельности студентов в процессе изучения медицинской информатики в медицинском вузе / Е. В. Плащевая, Н. В. Нигей // Тенденции развития науки и образования. - 2021. - № 75-4. - C. 124-127.

\section{Подложнюк Е.А., Кадеева О.Е. \\ Формирование функциональной математической грамотности на уроках математики}

Дальневосточный федеральный университет (Россия, Владивосток)

doi: 10.18411/trnio-01-2022-151

\section{Аннотация}

В данной статье представлена проблема формирования функциональной математической грамотности на уроках математики, рассмотрены практикоориентированные задачи как средство формирования функциональной математической грамотности.

Ключевые слова: функциональная грамотность, математическая грамотность, практико-ориентированные задачи. 